Article

\title{
The Status and Evolution of Energy Supply and Use in Mexico Prior to the 2014 Energy Reform: An Input-Output Approach ${ }^{\dagger}$
}

\author{
Zeus Guevara ${ }^{1,3, *}$, Oscar Córdoba ${ }^{2}$, Edith X. M. García ${ }^{1}$ and Rafael Bouchain ${ }^{3}$ \\ 1 University Center of Tonalá, University of Guadalajara, Avenida Periférico 555, Ejido San José Tatepózco, \\ Jalisco 48525, Mexico; Edith.Garcia@cutonala.udg.mx \\ 2 Faculty of Economy, National Autonomous University of Mexico, Circuito Interior s/n, \\ Ciudad Universitaria, Coyoacán, Mexico City 04510, Mexico; ocr@ciencias.unam.mx \\ 3 Institute of Economic Research, National Autonomous University of Mexico, Circuito Mario de la Cueva s/n, \\ Ciudad Universitaria, Coyoacán, Mexico City 04510, Mexico; bouchain@unam.mx \\ * Correspondence: zguevara@iiec.unam.mx; Tel.: +521-56230100 (ext. 42362) \\ + This paper is an extended and improved version of our papers presented in the 23rd International \\ input-output conference, Mexico City, 23-26 June 2015, and in the VI Jornada de Análisis Input-Output, \\ Barcelona, Spain, 7-9 September 2015.
}

Academic Editor: Lea-Rachel Kosnik

Received: 25 November 2016; Accepted: 17 March 2017; Published: 21 March 2017

\begin{abstract}
In 2014, the Mexican government approved a bold energy reform that allows private energy companies to freely participate in the energy market (something prohibited during the previous eight decades). This reform is expected to significantly restructure the energy sector and boost and diversify the energy production. Moreover, changes in the energy sector and production might lead to structural changes in the rest of the economy and ultimately generate significant economic benefits for the country. Nevertheless, the fundamental role of the energy sector in this oil producing country makes the potential impacts of the reform complex to forecast. The objective of the study is to analyze the current state, evolution, and driving factors of the total primary energy use in Mexico in 2003-2012 (prior to the implementation of the reform) as a precedent for future analyses of impacts of the energy reform. The results show three driving factors of the evolution of primary energy use: final non-energy demand, direct energy intensity, and economic structure. Also, it was found that the energy sector has been in a precarious situation regarding its structure and efficiency. However, this situation had a small effect on the evolution of primary energy use.
\end{abstract}

Keywords: energy-economic transition; Mexican energy reform; energy input-output analysis

JEL Classification: Q43; O13

\section{Introduction}

The bold energy reform that the Mexican government approved in 2014 represents one of the most significant regulation changes to the energy sector in the last eight decades [1]. Before this reform, the processes of national energy resource exploitation and power generation were controlled by the state. In contrast, with the energy reform, all processes of energy exploitation and generation are opened to private companies (national and foreign). Also, the reform changes the scope of state-owned companies and creates new regulatory agencies, while reorganizing existing ones. Therefore, it is expected that the proposed regulation will significantly affect the structure of the energy sector and the characteristics of energy use and production in the country $[2,3]$. 
The energy reform will likely have a large (positive or negative) effect on the economy since Mexico is an oil country, i.e., it has the seventeenth position in oil reserves [4]. Its economy depends heavily on exports of crude oil, which account for over $15 \%$ of total exports and cover $37 \%$ of government revenues $[5,6]$. The government expects that this reform boosts oil production, attracts new technologies and capital, and allows the exploitation of non-conventional oil and gas reserves. However, a potential, though not-desired, effect of the energy reform could be the reduction of oil-related government revenues and, in turn, public spending, due to revenues being diverted to the private sector.

Despite being an oil-producing country, Mexico does not have the industrial capacity to generate its own demand for oil derivatives, meaning that these are imported. This situation causes the prices of these products for the industry and final consumers to be relatively higher than in the U.S. [7]. Regarding this, the government expects more investment from private companies, which stimulates the construction of new refineries and reduces fuel prices [2]. Moreover, the energy reform aims to increase the number of private power companies on the assumption that increased competition in the electricity sector would lead to reductions of electricity prices, improvements in electric supply, and growth in renewable energy production.

The expected changes in the energy sector will also have to deal with the increasing energy demand by other sectors of the economy. The residential sector consumed around $52 \%$ of the total use of secondary energy flows before 2015 [8], including residential private transportation, which accounted for $35 \%$ of total energy use and $98 \%$ of total gasoline use $[8,9]$. Even though oil derivatives have had the largest share in residential energy use [10], electricity use by residential consumers had the largest growth rate between 1970 and 2012 [10-12], reaching $22 \%$ of the total electricity use in the country $[8,13]$. The transportation sector accounted for around $7.7 \%$ of the total use of secondary energy flows (not including residential private transportation) [8]. Moreover, all transportation energy uses (including residential uses) increased by 66\% between 1990 and 2012, driven by the increased demand for private vehicles and light truck transportation $[14,15]$. The energy demand by the industrial sector (including primary industries) increased $8 \%$ in the decade to 2012. However, its share of total secondary energy use fell to $36.8 \%[8,15]$. In addition, the service sector increased its energy use by $15 \%$ in the period 2003-2012, though it held an almost constant share of 3.2\% of total secondary energy use [8].

Furthermore, in academic and specialist circles, there are two perspectives about the potential impacts of this reform.

On the one hand, the first perspective agrees with the benefits expected by the government (see SEGOB [2]), which include renewable energy deployment, increases in exports, poverty alleviation, a productivity rise, and GDP growth, all induced by the maximization of oil revenues and the liberalization of energy markets [16-22]. Most of the authors that support this perspective believe that the implementation of the energy reform, rather than its content, and the government's capacity to balance conflicting interests and compensate negative externalities will be key factors for the energy reform success; for example, see Schulz et al. [21].

On the other hand, the second perspective criticizes the energy reform and expects more losses than benefits from its implementation. The criticism is centered around five areas: (1) the content has complex energy market regulations, does not specifically approach current performance problems of energy industries, and could induce the depletion of oil reserves [23-31]; (2), the approval process of the reform presented irregularities and a lack of transparency [31-33]; (3) the experience of similar reforms in other countries (e.g., Brazil) shows that this reform is likely to induce wealth transfer abroad [34,35]; (4) the reform could cause repercussions to the economic structure such as separation of the energy sector from the rest of the economy [36-38] and the decline of existing energy industries that are unable to compete [28-31,39]; (5) also, the benefits to others sectors depend on uncertain international energy prices [31,40,41]; and (6) the lack of specific measures to achieve social and environmental sustainability could lead to the reduction of renewable energy production $[26,28,42,43]$ and abuses of vulnerable populations $[23,28,34,44]$. 
The negative and positive impacts of the 2014 energy reform are difficult to forecast without a proper understanding of the state and evolution of energy production and consumption in the country prior to the implementation of the reform. In this respect, the paper analyzes the current state, evolution, and driving factors of the trend of primary energy use in the country during the period 2003-2012, with special emphasis on the structure of the energy sector.

The analysis is approached with the multi-factor energy input-output model, developed by Guevara and Rodrigues [45] and Guevara and Domingos [46], which provides a detailed description of energy flows and of the structures of the energy sector and the rest of the economy. Moreover, the analysis is complemented with the structural decomposition methodology that allows the driving factors of economy-wide indicators to be identified [47].

The present paper constitutes a precedent for future analyses of the impacts of the energy reform. Also, it contributes to the scarce literature about the trends of economy-wide energy use and supply in Mexico. Guevara et al. [6] summarized most of previous energy research about Mexico and pointed out that it had been mainly focused on sectoral analysis, addressing the residential, industrial, and transport sectors or specific industries; see [10-15,48-53].

Regarding economy-wide studies of Mexico, Aguayo and Gallagher [54] found that compositional factors and technological progress in energy-intensive industries were the main driving factors of the trend of primary energy intensity in 1965-1999. Guevara et al. [6] estimated the useful energy use trends in 1971-2009. They found that the useful energy use had a six-fold growth, led by the use of mechanical drive, and that the useful energy intensity slightly increased. In addition, Sheinbaum et al. [55] concluded that the decrease in the energy intensity of Mexico and four other Latin American countries between 1990 and 2006 did not lead to a significant reduction in $\mathrm{CO}_{2}$ emissions because of an increased share of fossil fuels in the primary energy mix.

Finally, there are two non-related studies about primary energy requirements in Mexico under the input-output framework. The first, by Ortiz [56], studied the period 1971-2007 using the input-output model of the energy sector by Alcántara and Roca [57] (presented in Section 2.1.1), which analyzes the interindustry energy flows within the energy sector in isolation [46]. He found that the increase in the final demand for oil derivatives led to a reduction in the efficiency of energy industries. The second, by Livas-García [58], studied the period 1970-2010, using the same input-output model of the energy sector combined with structural decomposition analysis. He concluded that energy consumption was the main influential factor on the trend of primary energy use. It is worth mentioning that the model used in these two studies disregards the structure of the rest of the economy and the final non-energy demand (which are included in the present study).

The present paper is structured as follows. Section 2 presents the methodology and describes data processing. In Section 3, decomposition results are described. Finally, in Section 4, the main insights from the work are discussed.

\section{Methodology}

The present study is based on the methodology of energy input-output analysis (EIO analysis), which is designed to account for the energy flows in the economy [59-61]. Specifically, the multi-factor input-output model of primary energy use, developed by Guevara and Rodrigues [45] is applied to the evaluation of energy supply and use in Mexico in the period 2003-2012. This model was selected because it offers a more detailed description of the energy flows according to the processes of energy conversion and use in the economy. Moreover, in combination with structural decomposition analysis, the model allows the evolution of primary energy use to be evaluated, separately accounting for the effect of several factors on changes in primary energy use.

The notation used in this section and in the remaining of the document is as follows: a bold lower case letter $(x)$ corresponds to a vector; a bold capital letter $(Z)$ describes a matrix or sub-matrices; non-bold Latin letters $\left(x_{i}\right.$ and $\left.z_{i j}\right)$ represent matrix entries, vector elements, scalars, and indexes; 
a vector with a hat $(\hat{x})$ represents a diagonal matrix, whose diagonal elements are the elements of vector $x$; and $i$ is a vector of ones of a consistent length (or summation vector).

\subsection{The Multi-Factor Input-Output Model of Primary Energy Use}

The model is composed by four sub-models (Sections 2.1.1-2.1.4) that are then coupled into a complete model of primary energy use in Section 2.1.5.

It describes an economy that consists of $n_{C}$ energy products, $n_{T}$ energy industries, $n$ non-energy products, $n_{S}$ non-energy industries of the rest of the economy, and one final demand sector.

\subsubsection{The Sub-Model of the Energy Sector (in Physical Units)}

$$
g=Z^{E} i+\left(C^{E} e+h\right) i=A^{E} g+\left(C^{E} e+h\right) i=L^{E}\left(C^{E} e+h\right) i
$$

where

- $\quad$ vector $g$ is the total output by product of the energy sector (total energy use);

- matrix $Z^{E}$ is the interindustry transactions between energy industries;

- matrix $A^{E}$ is the technical coefficients of the energy sector, $=Z^{E} \hat{g}^{-1}$;

- matrix $L^{E}$ is the total primary-to-secondary energy requirements, $=\left(I-A^{E}\right)^{-1}$;

- matrix $C^{E}$ is the composition of intermediate energy demand by non-energy industries;

- $\quad$ vector $e$ is the aggregate intermediate energy demand by non-energy industries; and

- $\quad$ vector $h$ is the energy deliveries to final consumers, i.e., final energy demand.

The elements $Z^{E}$ and $C^{E} e$ correspond to the sub-matrices of the matrix of interindustry energy flows in the economy $(E)$ of the basic input-output model of energy flows $(g=E i+h)$; see, Alcántara and Roca [57], Guevara and Domingos [46], and Miller and Blair [59].

2.1.2. The Sub-Model of the Rest of the Economy (in Monetary Units)

$$
x^{S}=L^{S} f
$$

where

- $\quad$ vector $x^{S}$ is the economic output of the rest of the economy;

- matrix $L^{S}$ is the total non-energy requirements of the rest of the economy. It corresponds to the economy-wide inverse Leontief matrix without the rows and columns of energy industries; and

- $\quad$ vector $f$ is the final non-energy demand.

2.1.3. The Sub-Model of the Direct Energy Intensity (in Mixed Units)

$$
T^{E}={\widehat{e} x^{S}}^{-1}
$$

where matrix $T^{E}$ is the direct energy intensity by non-energy industries (i.e., intermediate energy demand by non-energy industries per unit of total production).

2.1.4. The Sub-Model of Primary Energy Use (in Physical Units)

$$
p=\hat{k} g
$$

where scalar $p$ is the total primary energy use and vector $k$ (constant) is a bridge vector that selects primary energy flows. 


\subsubsection{The Complete Input-Output Model}

Coupling the sub-models in Equations (1)-(4), the final form of the input-output model of primary energy use is:

$$
p=\underbrace{\hat{k} L^{E} C^{E} T^{E} L^{S} f}_{\begin{array}{c}
\text { Caused by final } \\
\text { non-energy demand }
\end{array}}+\underbrace{\hat{k} \underbrace{L^{E} h}}_{\begin{array}{c}
\text { Caused by final } \\
\text { energy demand }
\end{array}},
$$

The model includes two energy efficiency indicators $\left(L^{E}\right.$ and $\left.T^{E}\right)$, two variables of end-use energy consumption $\left(C^{E}\right.$ and $\left.h\right)$, and two economic variables $\left(L^{S}\right.$ and $\left.f\right)$.

\subsection{Structural Decomposition Analysis}

Decomposition analysis is a numerical method that identifies the driving forces behind changes in economy-wide indicators $[47,62,63]$. Since the 1980s, it has been applied to studies of energy and environmental indicators [47,64], as well as to policy analysis [47,65-67].

The specific decomposition methodology for the input-output framework is the structural decomposition analysis (SDA), which is able to study the effects of changes in the structural factors of the economy $[59,63]$. According to the SDA, changes in $p$ can be decomposed into decomposition coefficients (a.k.a. effects or contributions) of its constitutive factors, so for the model in Equation (5), the decomposition of the primary energy use is represented as:

$$
\Delta p=\delta L^{E}+\delta C^{E}+\delta T^{E}+\delta L^{S}+\delta f+\delta h
$$

where $\delta x$ is a decomposition coefficient of the contribution of variations in factor $x$ to primary energy use changes. Each coefficient is discussed below:

- $\delta L^{E}$ is the effect on $\Delta p$ of changes in the structure and efficiency of the energy sector, e.g., an efficiency reduction in oil refining or the closure of coal-fired power plants;

- $\delta C^{E}$ is the effect on $\Delta p$ of changes in the direct energy demand composition, e.g., the shift from coal to electricity for iron melting;

- $\delta T^{E}$ is the effect on $\Delta p$ of changes in direct energy intensity, e.g., a reduction in the energy demand per unit of economic ouput of chemical industries;

- $\delta L^{S}$ is the effect on $\Delta p$ of structural changes in the rest of the economy, e.g., a relative increase of interindustry demand for services by the rest of the economy;

- $\quad \delta f$ is the effect on $\Delta p$ of changes in final non-energy demand, e.g., a reduction in the use of electric equipment by final consumers; and

- $\quad \delta h$ is the effect on $\Delta p$ of changes in residential energy demand, e.g., a decrease in the residential use of wood for space heating.

The decomposition coefficients in Equation (6) were determined through the complete D\&L procedure, developed by Dietzenbacher and Los [68], which calculates each coefficient as the average of all decomposition forms; see Seibel [69] and De Haan [70]. This technique offers complete decomposition (no residual term) and zero-value and negative-value robustness [62,65].

The present study is inserted in the literature of SDA applied to energy and emissions, which has rapidly grown in the last two decades. In this respect, Su and Ang [65] made a compilation of these types of studies between 1999 and 2010. They found 44 SDA studies, most of which used the D\&L procedure. Moreover, Guevara [71] updated this compilation for 2014, adding 28 studies. He found that SDA studies applied to energy and emissions from 1995 to 2014 mainly used the direct impact coefficient input-output model instead of the more theoretically-sound hybrid input-output model; see Guevara and Domingos [46], Casler and Wilbur [60], and Miller and Blair [59].

Furthermore, the SDA method described by Equation (6) corresponds to additive decomposition, which decomposes changes in an indicator as a summation of factor coefficients. The other option is the 
multiplicative decomposition, which decomposes changes in an indicator as a multiplication of factor coefficients; see [72] and [73]. Additive SDA is the most used in energy and emission studies both for analyzing absolute (e.g., total emissions) and relative (e.g., energy intensity) indicators [65,71] despite multiplicative SDA being more suitable for studying relative indicators [62,74]. The combination of multiplicative SDA with the multi-factor input-output model in Section 2.1 for the analysis of relative energy indicators constitutes a direction for further research.

\subsection{Data Processing}

Energy flow data from the Ministry of Energy's balances [8] were used to build the energy sector sub-model (Section 2.1.1) according to the commodity-by-industry approach to input-output analysis [59,75], as done by Guevara and Rodrigues [45]. In this approach, energy data is arranged into supply and use tables (see Supplementary Information), which consist of $n_{C}=47$ energy products, $n_{T}=15$ energy industries, $n_{S}=24$ non-energy industries of the rest of the economy of direct energy demand, and one sector of final energy demand (i.e., residential); see Appendix A. Moreover, energy uses for private transportation were allocated to the residential sector by separating these uses from the energy data of the road transport industries (as most energy databases aggregate industrial and residential energy use for transportation). This was done based on data of other OECD countries $[4,76]$ since the energy balances of Mexico do not include information on residential transportation.

The sub-model of the rest of the economy was built with the domestic input-output tables at current prices from the National Institute of Statistics and Geography [77], which are only available for the years 2003, 2008, and 2012. The 2003 and 2008 tables have a classification of $m=250$ industries (of which $m_{S}=247$ are non-energy industries). The 2012 table has a classification of $m=800$ industries (of which $m_{S}=788$ are non-energy industries). Due to the different classification system, the 2012 table was harmonized into the 2003 and 2008 tables' classification through aggregations. Furthermore, to perform a temporal comparison, it was necessary to convert the data from current to constant prices $[59,78]$. This was done by deflating/inflating the entire dataset with the appropriate chain indices $[79,80]$. Notice that due to the lack of domestic input-output tables for most years in the period 2003-2012, the present SDA analysis might include temporal aggregation issues, as explained by Su and Ang [81].

Furthermore, as is done by Guevara and Rodrigues [45], the matrix of direct energy intensity $\left(T^{E S}\right)$ is built so that it performs the necessary transformations between the SENER's and INEGI's classifications for non-energy industries $\left(n_{S}\right.$ versus $\left.m_{S}\right)$.

Finally, the primary equivalent of renewable energy flows was estimated by the physical content method [82-86], which estimates the primary equivalent as the energy content of the first usable form of renewable flows (i.e., electricity or heat). Accordingly, the primary equivalent of secondary energy imports was calculated under the domestic technology assumption, which estimates the primary equivalent as the amount of primary energy that would have been necessary for domestic energy industries to produce all imports of secondary energy flows.

\section{Results}

The results of the input-output and decomposition analyses are presented in the following sections. Section 3.1 presents a description of the state and the evolution of energy use and of its constitutive factors (see Equation (6)). Section 3.2 identifies the driving factors of the evolution of energy use.

\subsection{State and the Evolution of Primary Energy Use}

\subsubsection{Primary and Secondary Energy Use $(P \& G)$}

The total primary energy use (PEU) was 6183.13 PJ in 2003 with a renewable share of $6.34 \%$. Afterwards it grew to $7295.67 \mathrm{PJ}$ with $7.57 \%$ of renewables in 2008 and to 7515.13 PJ with $7.43 \%$ of renewables in 2012. In between 2003 and 2008, there was a significant increase in the use of some 
non-conventional renewable sources (up to four times) such as geothermal, wind, biogas, and firewood. In the second sub-period (2008-2012), solar energy achieved the largest increase. However, these primary sources remained negligible in the primary energy mix of the country (less than a $2 \%$ share).

Regarding secondary energy flows, the demand for oil derivatives in 2012 was three times larger than in 2003. This demand increase was mainly met by a rise in oil derivatives imports before 2008, though these imports remained almost constant after that year. In addition, electricity consumption had a $35 \%$ increase over the whole period.

Over 2003-2008, residential consumers significantly increased the use of gasoline and diesel for transportation (32\% and $46 \%$, respectively), while reducing the use of kerosene and natural gas; service industries increased the use of diesel by $50 \%$ and consumed less electricity by $26 \%$; manufacturing and primary industries consumed more diesel, petroleum coke, peat, and electricity and reduced the use of kerosene and fuel oil; and transportation industries increased the use of gasoline and diesel by over $30 \%$ and decreased the use of LPG by $21 \%$. Over 2008-2012, residential consumers did not significantly increase the use of most carriers, except for kerosene and PV electricity (increasing by $45 \%$ and $32 \%$, respectively); service industries increased the use of electricity by over $60 \%$, while maintaining the same level of consumption of other carriers; manufacturing and primary industries significantly reduced their use of coal and fuel oil and consumed more electricity; and transportation industries consumed less diesel by $5 \%$ and stopped using fuel oil.

\subsubsection{Structure and Efficiency of Conversion Processes in the Energy Sector $\left(L^{E}\right)$}

There were improvements in the efficiency of conversion processes in oil refineries, nuclear electric generation plants, and coal refineries by 2012 with respect to 2003 . However, conventional thermoelectric generation decreased its aggregate efficiency between 2008 and 2012 (42\% to 40\%). Moreover, the electric grid for distribution and gas work facilities had a poor performance during the period under study (i.e., efficiency reductions of $1 \%$ and $15 \%$, respectively).

The change in the total primary-to-secondary energy requirements $\left(L^{E}\right)$, represented by the ratio of matrix entries $\left(L_{i j}^{E}\right)$ between one year and another, are shown in the form of heat maps (Figure 1). The rows of $L^{E}$ describe the primary energy flows that go into the conversion processes of energy industries, while its columns describe the total energy requirements needed to provide a unit of final or intermediate energy demand by these industries. The classification of energy flows and technologies are presented in Appendix A.

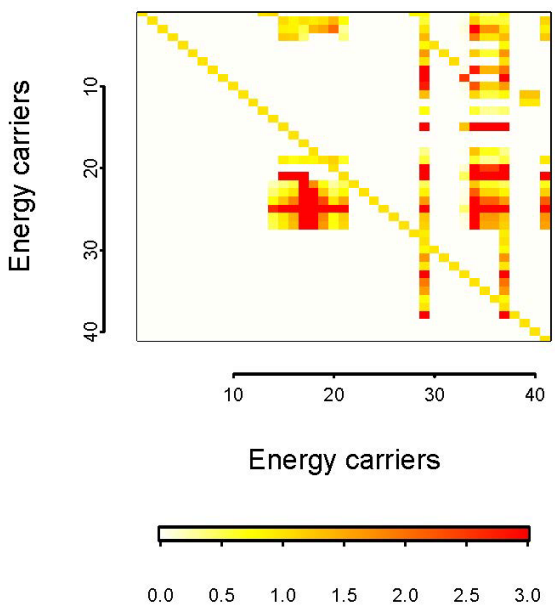

(a)

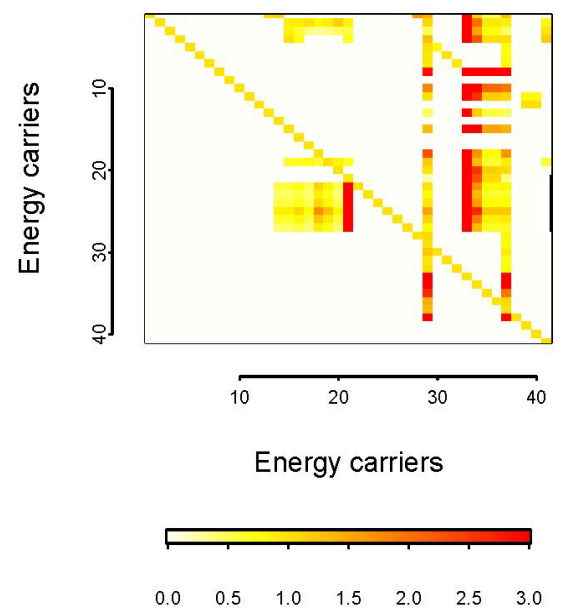

(b)

Figure 1. Heat map of element-wise ratio $L_{Y 2}^{E} / L_{Y 1}^{E}$ between 2003 and 2008 (a) and between 2008 and 2012 (b). Notes: The $L^{E}$ matrix represents the total energy requirements of the energy sector; the horizontal and vertical axis indicates the indexes of energy carriers, whose classification (indexes and names) is presented in Appendix A; ratios of three or above are represented in dark red color. 
The zone around the center of the matrix (columns 14-20 and 22) corresponds to oil refineries. Between 2003 and 2008, these industries were unable to satisfy intermediate and final demand, which is inferred by the larger amount of crude oil inputs (rows 2-3) and oil and natural gas imports (rows 23-31) that were needed to satisfy a unit of demand for oil derivatives in 2008 than in 2003. Nevertheless, in the sub-period 2008-2012, the total requirements of crude oil and oil and gas imports to provide a unit of intermediate and final energy demand for these products did not have large variations (values in the heat map in between 0.7 and 1.2). It is worth mentioning that in the whole period under study, the government failed to build new refineries and current refineries did not significantly increase production.

The total requirements to deliver a unit of natural gas to final and intermediate consumers (column 21) increased over the whole period 2003-2012, especially after 2008. Figure 1a,b show that there was an increase in the total requirements of oil and gas imports (rows 23-31) needed to satisfy domestic demand for natural gas, especially after 2008.

Conventional thermoelectric generation (columns 32-33) became less efficient in the whole period as the total requirements of most energy carriers needed to provide a unit of thermoelectricity to final and intermediate demand increased. The same happened with some renewable power technologies (columns 37-41) such as wind, solar, and biogas-fueled power generation, which experienced a rise in their total requirements of oil derivatives needed to meet final and intermediate demand.

\subsubsection{Composition of Intermediate Energy Demand $\left(C^{E}\right)$}

This matrix represents the share of each energy product in the intermediate demand by non-energy industries. The comparison between 2003 and 2008 shows a higher share for Kerosene, LPG, and electricity in the energy demand by most non-energy industries except in the agriculture, steel, chemical, and sugar industries. In addition, there was a reduced demand share of fuel oil in most non-energy industries. From 2008 to 2012, the share in the consumption of Kerosene, LPG, and electricity continue increasing. Moreover, the demand share of fuel oil and petroleum coke decreased in most industries in the second sub-period.

\subsubsection{Direct Energy Intensity $\left(T^{E S}\right)$}

Between 2003 and 2008, the direct energy intensity of primary industries increased, which implies that they became less efficient ( $37 \%$ efficiency decrease). Also, the iron and steel, mining, rail transport and road transport industries had poor energy performances (20\% to $43 \%$ efficiency decrease). On the other hand, the sugar, beer, paper and pulp, chemical fertilizer, and rubber industries had the largest efficiency improvements (above 15\% efficiency increase).

The changes between 2008 and 2012 were less significant, highlighting the inefficient trend of the mining, rubber, and tobacco industries (above 30\% efficiency decrease) and the improvements in the petrochemical, fertilizer, glass, and sugar industries (above 25\% efficiency increase).

\subsubsection{Requirements of the Rest of the Economy or Economic Structure $\left(L^{S}\right)$}

This factor shows the changes in interindustry non-energy monetary transactions and the non-energy input structure of the rest of the economy (non-energy industries). In the sub-period 2003-2008, the economy-wide total requirements of construction services increased, as well as those of electronics, auto parts, public services, and motor vehicles. In contrast, the economy reduced the total requirements of a few goods and services such as wood products and telecoms services.

Between 2008 and 2012, changes in this factor were not significant, i.e., the total requirements hardly change in most industries. Nevertheless, there was an increase in the intermediate demand for electronic equipment, automobiles, and utilities. On the other hand, industries of electronic equipment significantly increased their total requirements per unit of final demand. 


\subsubsection{Final Non-Energy $(f)$ and Energy $(r)$ Demand}

Final non-energy demand for products of the primary, pulp and paper, automotive, telecom and financial services industries increased during the first sub-period. On the contrary, between 2008 and 2012, the consumption of non-energy goods and services had little variation, except for the demand for electric equipment and financial services that significantly increased.

Residential consumption of fuels for transportation, photovoltaic electricity, grid electricity, and firewood increased (especially the use of gasoline and diesel, which increased by more than $30 \%$ ) while the consumption of LPG, natural gas, and Kerosene was reduced in the sub-period 2003-2008. In the second sub-period, the consumption of LPG, gasoline, diesel, natural gas, and firewood had little variation $( \pm 5 \%)$. Contrariwise, the residential consumption of grid electricity and photovoltaic electricity increased by $11 \%$ and $32 \%$, respectively.

\subsection{Main Drivers of Primary Energy Use Change}

The following Table 1 presents the results of the structural decomposition analysis of PEU in Mexico 2003-2012.

Table 1. Structural decomposition analysis (SDA) coefficients of primary energy use (PEU) in México 2003-2012.

\begin{tabular}{cccccccc}
\hline sub-period & $\Delta p$ & $\delta L^{E}$ & $\delta C^{E}$ & $\delta T^{E S}$ & $\delta L^{S}$ & $\delta f$ & $\delta h$ \\
\hline $2003-2008$ & 1112.54 & -1.01 & 37.09 & -139.64 & -192.52 & 778.48 & 630.14 \\
$2008-2012$ & 219.46 & 104.51 & 161.77 & -289.19 & -69.03 & 261.41 & 50.00 \\
$2003-2012$ & 1332.01 & 103.50 & 198.86 & -428.83 & -261.56 & 1039.88 & 680.15 \\
\hline \multicolumn{8}{c}{ Units PJ. }
\end{tabular}

Between 2003 and 2008, PEU had a significant increase (1112.54 PJ), which was mainly caused by changes in final non-energy and energy demand $(f$ and $h)$. Particularly, the increase in residential energy use for private transportation was the main influence on $\delta h$ (though other residential energy uses also increased). Also, the composition of intermediate energy demand $\left(C^{E}\right)$ had a small effect on raising the PEU. Moreover, despite the poor performance and deterioration of the energy sector in this sub-period (see Figure 1 of $L^{E}$ ), changes in the structure and efficiency of this sector did not have a significant effect on the PEU trend. On the other hand, structural changes in the rest of the economy $\left(L^{S}\right)$ and the direct energy intensity $\left(T^{E S}\right)$ contributed to reducing PEU. The former implies that the rest of the economy had a transition to non-energy industries that had lower energy intensity (e.g., services), used inputs more efficiently, and/or required inputs with less primary energy content, while the latter implies that improvements in the economic-energy efficiency in some non-energy industries (e.g., chemical) offset the effect of reductions in the energy-production performance in other non-energy industries (e.g., iron and steel and road transport).

During the second sub-period, PEU grew to a lesser extent than in the previous sub-period. Structural changes in the rest of the economy $\left(L^{S}\right)$ continue having an effect on reducing PEU, but this is much smaller than in 2003-2008. This might have been influenced by the international crisis that did not allow significant improvements in the production processes of non-energy industries. The structure and efficiency of the energy sector $\left(L^{E}\right)$ contributed to increasing PEU due to the reduction of the efficiency in several conversion processes, e.g., thermoelectric generation. Changes in the composition of direct energy demand $\left(C^{E}\right)$ had a significant effect on increasing PEU because of the increased demand for LPG and electricity (carriers with high associated PEU). Final demands (energy $h$ and non-energy $f$ ) were the main driving factor of PEU change. However, these factors reduced their contribution (as compared to the first sub-period) because of world crisis-related reductions in expenditures by residential consumers. Finally, the direct energy intensity had the largest effect of reducing PEU, which was caused by improvements in some non-energy industries, especially in the glass industry, which is highly energy intensive. 
Furthermore, Figures 2 and 3 present SDA coefficients in sectoral detail to show the driving factors of PEU changes that are related to the direct energy intensity and final demand of specific industries.

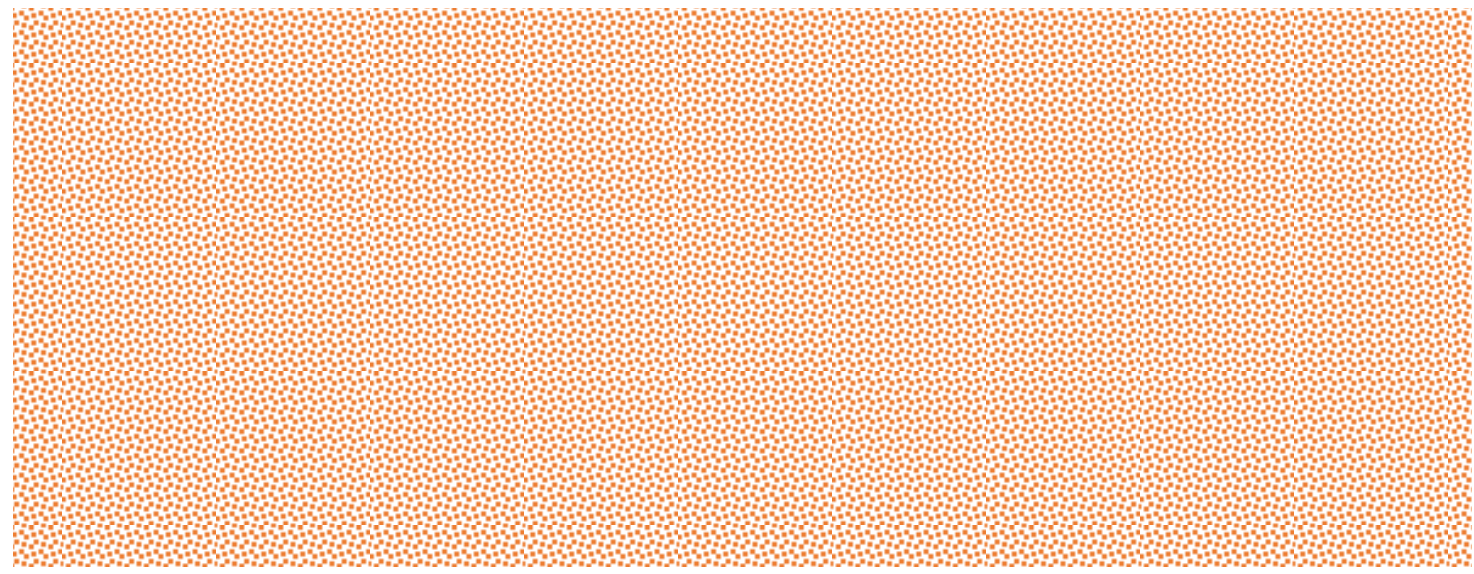

Figure 2. SDA coefficients in sectoral detail with respect to PEU changes related to the direct energy intensity and total requirements of specific non-energy industries in México 2003-2012. Notes: These coefficients were calculated considering the isolation of columns of $T^{E S}$ (implying also the isolation of rows of $L^{S}$ ); SDA coefficients are presented in relative terms (percentages).

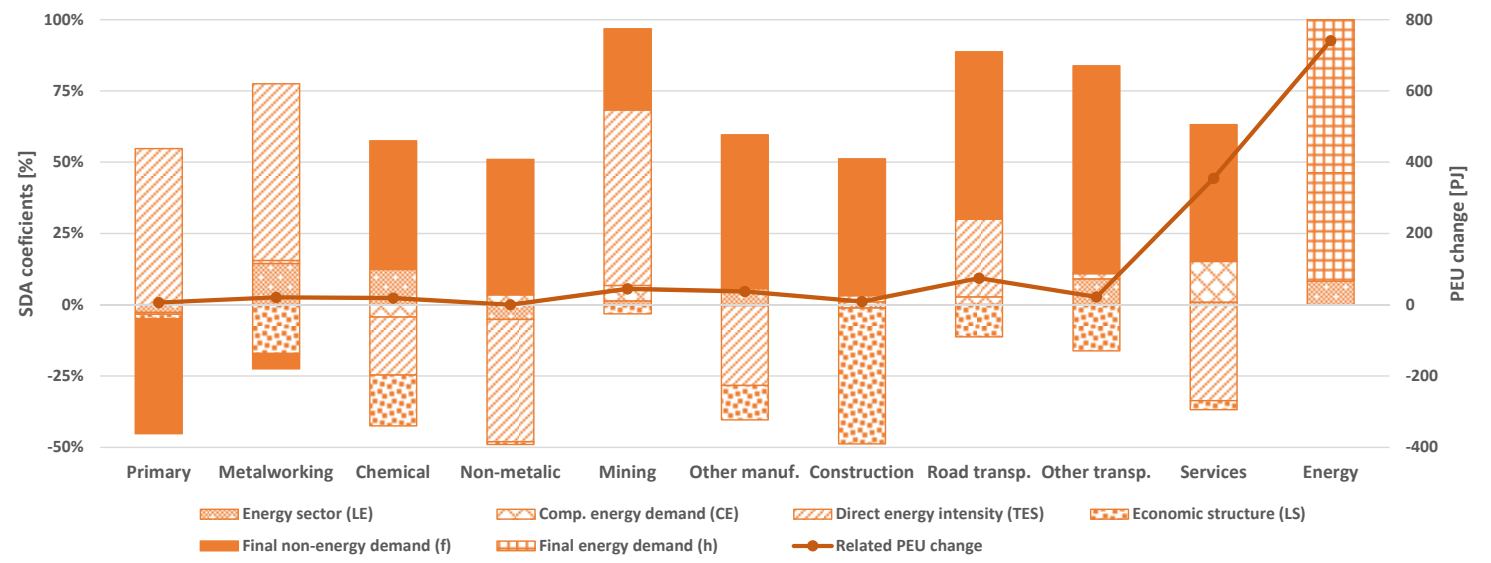

Figure 3. SDA coefficients in sectoral detail with respect to PEU changes related to the final demand and input structure of specific non-energy industries in México 2003-2012. Notes: These coefficients were calculated considering the isolation of rows of $f$ (implying also the isolation of columns of $L^{S}$ ); SDA coefficients are presented in relative terms (percentages).

The total requirements for services in the economy had the largest related PEU change, which was driven by the increase in total final non-energy demand and the change in the composition of direct energy demand. The effect of these driving factors was not offset by the effect of improvements in direct energy intensity. However, the energy intensity of services accounted for most of the overall effect of reducing the PEU of $T^{E S}$ (Table 1). Moreover, the related PEU change in the total requirements for the products of other non-energy industries was smaller than $40 \%$ of that for services, being related to the total requirements for primary products and road transport, the second and third largest sectors, respectively. The energy intensity of primary products, metalworking, mining, and road transport had the effect of increasing PEU due to their poor energy performances. On the other hand, changes in the total requirements (accounted for by $L^{S}$ ) had the effect of reducing PEU for most industries (except for the primary products and chemical industries). It is worth mentioning that changes in the energy sector had little effect on the PEU changes related to the total requirements for the products of non-energy industries. 
Services and energy demand by final consumers had the largest related PEU change, several times larger than the PEU change related to final demand of the other industries. Final demand for services accounted for most of the overall effect of energy intensity $\left(T^{E S}\right)$ and most of the composition of direct energy demand $\left(C^{E}\right)$. Changes in the final demand of most industries contributed to increasing PEU change, except for changes in the final demand of the primary and metalworking industries. The effect of the economic structure shows that most products reduced their total non-energy requirements, which implies a larger efficiency in the use of inputs of non-energy industries.

Finally, Figure 4 presents detail of SDA coefficients to show the driving factors of PEU changes related to the use of primary energy flows in the economy.

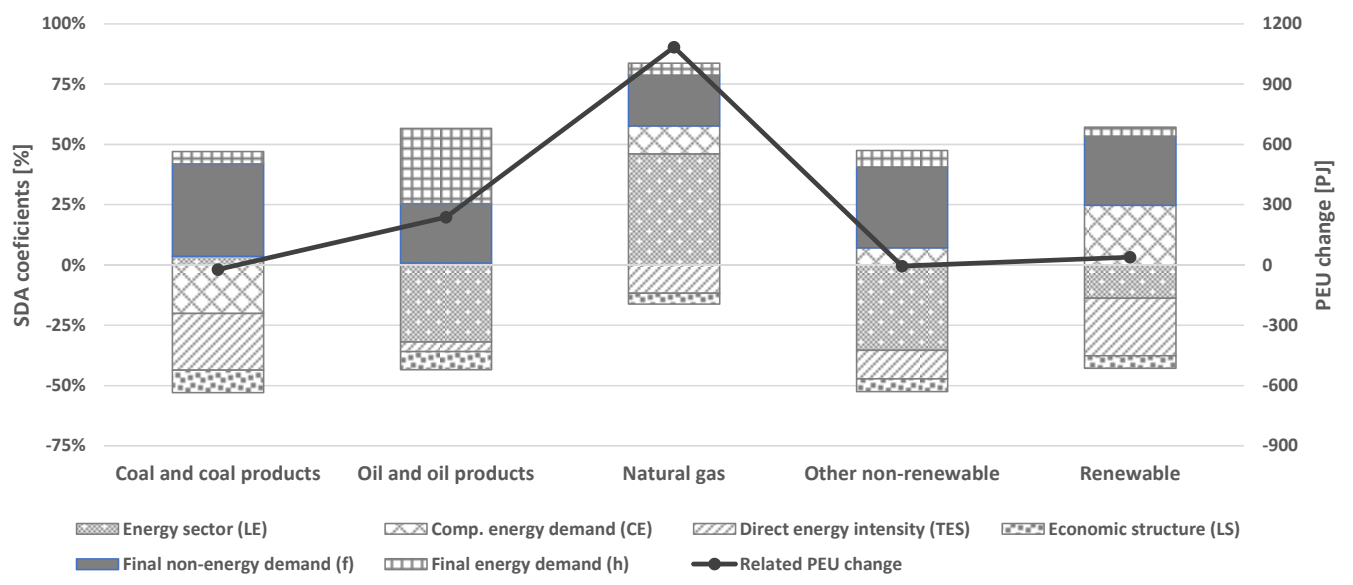

Figure 4. SDA coefficients with respect to PEU changes related to use of specific primary energy flows in México 2003-2012. Notes: These coefficients were calculated considering the isolation of rows of $L^{E}$; SDA coefficients are presented in relative terms (percentages).

Figure 4 shows that the total increase in PEU was driven by a significant increase in natural gas in the primary energy mix. Changes in the energy sector $\left(L^{E}\right)$ favored natural gas use instead of the use of oil and oil products, other non-renewable sources, and coal. This factor contributed to a reduction in the use of renewable primary flows, as well. Changes in the composition of direct energy demand also contributed to the transition in the primary energy mix by inducing a reduction of coal use and increases in the use of other non-renewable, natural gas, and renewable primary flows. Improvements in direct energy intensity contributed to reducing PEU for all primary energy flows. Moreover, changes in final non-energy demand had larger effects on increasing PEU than changes in final energy demand for most flows, except for oil and oil product primary flows.

\section{Discussion}

This paper presents an analysis of the status, evolution, and driving factors of primary energy use (PEU) in Mexico over the period 2003-2012.

Energy conversion technologies in the energy sector had a disappointing performance. Most national conversion technologies increased their energy requirements per unit of intermediate and final demand, which implies that either their processes became less efficient or that they were unable to satisfy the domestic energy demand, hence relying more in energy imports. Even more fossil energy flows were needed for the total requirements per unit of demand for some renewable energy technologies such as biogas-to-electricity and geothermal power. Moreover, the deficiencies in the energy sector were compensated with increases in energy imports rather than with efficiency improvements in energy industries (this fact suggests that the liberalization of energy markets, framed under the energy reform, could further harm the existing energy industries). In addition, there was a relatively significant increase in renewable energy production, but this was almost negligible in 
absolute terms. Nonetheless, despite the poor performance of the energy sector, it did not significantly contribute to the evolution of PEU.

Changes in the intermediate energy demand of the rest of the economy were also disappointing. On the one hand, non-energy industries did not significantly change their mix of energy demand; hence they did not favor more efficient carriers such as natural gas, which contributed to increasing PEU (especially during 2008-2012). On the other hand, the economic efficiency of direct energy use (i.e., direct energy intensity) of some strategic sectors such as iron steel, mining, and road transport did not experience improvements. However, the direct energy intensity contributed to significantly reducing PEU in the country. During 2003-2008, it was the second largest effect of decreasing PEU, becoming the largest in 2008-2012, which implies the positive impact of modest improvements in energy intensity in a few non-energy industries (especially the petrochemical and glass industries).

There was a rise in the total non-energy requirements to provide a unit of non-energy products to final demand (i.e., in average, non-energy industries required more inputs to produce the same), especially between 2003 and 2008. This rise was mainly associated with the increase in the use of non-energy products with less primary energy content (i.e., services); therefore, it contributed to reducing PEU.

Furthermore, sectoral results showed that the energy performance of service industries and final demand for services accounted for most of the effect of reducing the PEU of the direct energy intensity and the effect of increasing the PEU of final non-energy demand. Also, the energy performance and the flow of products to the final demand of other non-energy industries accounted for most of the effect of reducing the PEU of structural changes in the rest of the economy. In addition, residential energy use accounted for most of the effect of increasing the PEU of the structure and efficiency of the energy sector. These results suggest that regulations on the economic efficiency of the direct energy use of service industries, the final demand for services, and on residential energy use are fundamental to control the trend of PEU. However, the energy reform did not include any policy instrument to regulate energy consumption and the efficiency of industries and residential consumers.

The structural decomposition results show that there were four main driving factors of the evolution of primary energy use: (1) and (2) final non-energy and energy demand, which had the effect of increasing PEU; (3) structural changes in the economy, which contributed to decreasing PEU, mainly in the sub-period 2003-2008; and (4) the direct energy intensity, which had the largest effect of reducing PEU, especially in the sub-period 2008-2012.

The present study shows that energy supply and use in the Mexican economy has many areas of inefficiency. Particularly, the energy sector and intermediate energy demand have been in a precarious situation for many years. Changes in energy policy should have included measures to increase support to sustainable energy technologies and to energy efficiency, as well as measures to increase productivity and improve efficiency in existing energy industries (which would have likely caused the energy sector to contribute to reducing PEU, as has happened in several EU countries). Nevertheless, the approved energy reform is focused on increasing the production of primary fossil fuel energy and disregards specific measures to improve energy efficiency in the energy sector and the rest of the economy. Therefore, the reform would likely have the effect of increasing PEU.

Further research on this topic should be focused on three main areas: (1) understanding the status of the energy-economic relationships of Mexico (for example, through the analysis of the primary energy intensity) and between Mexico and US, as the energy reform may boost the integration of the energy sectors of these countries; (2) forecasting the impacts of the energy reform under different scenarios and time frames; and (3) evaluating the actual impact of the reform on the energy sector and on the economy when updated input-output data is available.

Supplementary Materials: The following are available online at www.mdpi.com/2227-7099/5/1/10/s1, Table S1: 2003 Energy Supply and Use Tables; Table S2: 2008 Energy Supply and Use Tables; Table S3: 2012 Energy Supply and Use Tables. 
Acknowledgments: This work was supported by the CONACYT-SENER Fund-Energy Sustainability 2015-2016, 2nd cut-off phase and by the PAPIIT Project No. IV300515 under the General Office of Academic Personnel of the National Autonomous University of Mexico. We also thank the valuable comments and suggestions of Paul Brockway at the University of Leeds.

Author Contributions: Rafael Bouchain arranged, harmonized, and deflected the economic input-output data and contributed to the writing of the paper; Oscar Córdoba arranged the energy balances data into the input-output system of the energy sector and contributed to the writing of the paper; Edith X. M. García helped perform decomposition calculations and contributed to the writing of the paper; and Zeus Guevara designed the study, integrated the arranged data to build the complete energy input-output model, performed decomposition calculations, and wrote most of the paper.

Conflicts of Interest: The authors declare no conflict of interest.

\section{Abbreviations}

The following abbreviations are used in this manuscript:

$\begin{array}{ll}\text { CONACYT } & \text { National Council for Science and Technology } \\ \text { D\&L } & \text { Dietzenbacher and Los decomposition procedure } \\ \text { EIO } & \text { Energy Input-Output } \\ \text { EU } & \text { European Union } \\ \text { INEGI } & \text { National Institute of Statistics and Geography } \\ \text { LPG } & \text { Liquefied Petroleum Gas } \\ \text { PEU } & \text { Primary Energy Use } \\ \text { PJ } & \text { Petajoule } \\ \text { SDA } & \text { Structural Decomposition Analysis } \\ \text { SENER } & \text { Mexican Ministry of Energy }\end{array}$

\section{Appendix A. Data Classification}

This appendix (Tables A1-A3) presents the classifications system of energy data used in this paper. For the extension, the classification system of economic data is not included.

Table A1. Classification of energy carriers.

\begin{tabular}{|c|c|c|c|c|c|c|c|}
\hline & Carrier & Source $^{1}$ & Type $^{2}$ & & Carrier & Source $^{1}$ & Type $^{2}$ \\
\hline 1 & Coal & FF & $\mathrm{P}$ & 25 & Gasoline imported & FF & S \\
\hline 2 & Crude oil & $\mathrm{FF}$ & $P$ & 26 & Kerosene imported & FF & $S$ \\
\hline 3 & Condensates & FF & $P$ & 27 & Diesel imported & FF & S \\
\hline 4 & Natural gas raw & $\mathrm{FF}$ & $\mathrm{P}$ & 28 & Fuel oil imported & FF & $S$ \\
\hline 5 & Nuclear energy & $\mathrm{NE}$ & $P$ & 29 & Petroleum coke imported & FF & S \\
\hline 6 & Hydro & RW & $\mathrm{P}$ & 30 & Natural Gas imported & FF & S \\
\hline 7 & Geothermal & RW & $\mathrm{P}$ & 31 & $\begin{array}{l}\text { Other oil derivatives } \\
\text { imported }\end{array}$ & FF & S \\
\hline 8 & Solar energy & RW & $\mathrm{P}$ & 32 & Electricity coal & FF & S \\
\hline 9 & Wind energy & RW & $P$ & 33 & Electricity thermoelectric & $\mathrm{FF}$ & $S$ \\
\hline 10 & Biogas & RW & $\mathrm{P}$ & 34 & Electricity nuclear & NE & S \\
\hline 11 & Peat & RW & $\mathrm{P}$ & 35 & Electricity hydro & RW & S \\
\hline 12 & Wood & RW & $P$ & 36 & Electricity geothermal & RW & $S$ \\
\hline 13 & Coal distributed & FF & S & 37 & Electricity wind & RW & S \\
\hline 14 & Coke & FF & $S$ & 38 & Electricity solar & RW & $S$ \\
\hline 15 & LPG & FF & $S$ & 39 & Electricity biogas & RW & S \\
\hline 16 & Gasoline & FF & S & 40 & Electricity peat & RW & S \\
\hline 17 & Kerosene & FF & $\mathrm{S}$ & 41 & Electricity grid distributed & $\mathrm{O}$ & $\mathrm{s}$ \\
\hline 18 & Diesel & FF & $\mathrm{S}$ & 42 & Electricity imported & $\mathrm{O}$ & $\mathrm{S}$ \\
\hline 19 & Fuel oil & FF & S & 43 & Peat distributed & RW & S \\
\hline 20 & Petroleum coke & FF & $S$ & 44 & Wood distributed & RW & $S$ \\
\hline 21 & Natural Gas distributed & $\mathrm{FF}$ & S & 45 & Other biomass imported & RW & S \\
\hline 22 & Other oil derivatives & FF & $S$ & 46 & Solar decentralized & RW & $S$ \\
\hline 23 & Coke imported & FF & $S$ & 47 & Non-energy oil derivatives & $\mathrm{FF}$ & $\mathrm{N}$ \\
\hline 24 & LPG imported & FF & $S$ & & & & \\
\hline
\end{tabular}


Table A2. Classification of energy industries.

\begin{tabular}{ll|ll}
\hline & Industry & \multicolumn{2}{l}{ Industry } \\
\hline 1 & Coke ovens & 9 & Hydroelectric power plant \\
2 & Oil refineries & 10 & Geothermal power plant \\
3 & Gas works & 11 & Wind power plant \\
4 & Coal plant & 12 & Solar energy power plant \\
5 & Thermoelectric power plant & 13 & Electric grid \\
6 & Independent power producer & 14 & Distribution of imported carriers \\
7 & Cogeneration & 15 & Biomass distribution \\
8 & Nuclear plants & & \\
\hline
\end{tabular}

Table A3. Sectoral classification of non-energy industries.

\begin{tabular}{ll|ll}
\hline & Industry & \multicolumn{1}{c}{ Industry } \\
\hline 1 & Primary & 6 & Other manufacturing \\
2 & Metalworking & 7 & Construction \\
3 & Chemical & 8 & Road transport \\
4 & Non-metallic & 9 & Other transport \\
5 & Mining & 10 & Services \\
\hline
\end{tabular}

\section{References}

1. SENER. Principales Características de la Reforma Energética; Secretaria de Energía: Mexico City, Mexico, 2014.

2. SEGOB. Reforma Energética: Explicación Ampliada; Secretaria de Gobernación: Mexico City, Mexico, 2014.

3. Espinasa, R.; López Córdova, E.; Padilla, M. Elementos Para el Diseño de una Estrategia Para Aumentar la Proveeduría Nacional de PEMEX; Banco Interamericano de Desarrollo: Mexico City, Mexico, 2014.

4. EIA. Petroleum and Other Liquids; U.S. Energy Information Administration: Washington, DC, USA, 2016.

5. INEGI. Exportaciones de Petróleo; Instituto Nacional de Estadística y Geografía: Mexico City, Mexico, 2015.

6. Guevara, Z.; Sousa, T.; Domingos, T. Insights on energy transitions in Mexico from the analysis of useful exergy 1971-2009. Energies 2016, 9, 488. [CrossRef]

7. EIA. Regular Gasoline Prices; U.S. Energy Information Administration: Washington, DC, USA, 2015.

8. SENER. Sistema de Información Energética; Secretaría de Energía: Mexico City, Mexico, 2015.

9. Sánchez, A.; Islas, S.; Sheinbaum, C. Demanda de gasolina y la heteregeneidad en los ingresos de los hogares en México. Investigación Econ. 2015, 74, 117-143. [CrossRef]

10. Sheinbaum, C.; Martínez, M.; Rodríguez, L. Trends and prospects in Mexican residential energy use. Energy 1996, 21, 493-504. [CrossRef]

11. Rosas, J.; Sheinbaum, C.; Morillon, D. The structure of household energy consumption and related $\mathrm{CO}_{2}$ emissions by income group in Mexico. Energy Sustain. Dev. 2010, 14, 127-133. [CrossRef]

12. Martínez-Montejo, S.A.; Sheinbaum-Pardo, C. The impact of energy efficiency standards on residential electricity consumption in Mexico. Energy Sustain. Dev. 2016, 32, 50-61. [CrossRef]

13. Mendieta, A.G. Determinantes de Consumo Eficiente de Energía Eléctrica en el Sector Residencial en México: Un Enfoque de Regresión Cuantílica; CIDE: Mexico City, Mexico, 2016.

14. Solís, J.C.; Sheinbaum, C. Energy consumption and greenhouse gas emission trends in Mexican road transport. Energy Sustain. Dev. 2013, 17, 280-287. [CrossRef]

15. Sheinbaum, C.; Mora, S.; Robles, G. Decomposition of energy consumption and $\mathrm{CO}_{2}$ emissions in Mexican manufacturing industries: Trends between 1990 and 2008. Energy Sustain. Dev. 2012, 16, 57-67. [CrossRef]

16. Ross, J. Algunas Tesis Equivocadas Sobre el Estancamiento Económico de México; El Colegio de México/UNAM: Mexico City, Mexico, 2013.

17. Lajous, A. Mexican Energy Reform; Columbia SIPA: New York, NY, USA, 2014.

18. Fisher, R.W. Ándale Pues! Having made the Tough Choices, Mexico Stands to Benefit from Reforms and Navigate Fed's Tapering with Relative Ease; Federal Reserve Bank of Dallas: Dallas, TX, USA, 2014. 
19. Gamiño, J.A.L.; Reyes, S.L.; Jiménez, S.F.L.; Cacho, S.I.R. La reforma energética y su impacto en un organismo decentralizado: El caso de la Comisión Federal de Electricidad. Eur. Sci. J. 2014, 10, 73-83.

20. Labardini, L.M. The Language of Energy Reform in Mexico. Lat. Am. Policy 2014, 5, 169-171. [CrossRef]

21. Schulz, M.; Rosenørn Engel, L.; Rasmussen, F. The Mexican Energy Reform: Finding the Balance between State Control and Development through Foreign Direct Investment; Roskilde Universitet: Roskilde, Denmark, 2015.

22. Alvarez, J.; Valencia, F. Made in Mexico: Energy Reform and Manufacturing Growth; International Monetary Fund: Princeton, NJ, USA, 2015.

23. Garaicochea Petrirena, F.; Barrios, H. La Legislacion Secundaria de la Reforma Energética [Radio Program]. In Momento Econ.; Radio UNAM: Mexico City, Mexico, 2014.

24. Garaiz, E. Reforma Energética: Una Visión Ciudadana Básica; ITESO: Jalisco, Mexico, 2014.

25. Montoya-MartínDelCampo, A. Reforma Energética: Traición a México; ITESO: Jalisco, Mexico, 2014.

26. Saldaña Zorrilla, S. 10 Consecuencias Económicas de la Reforma Energética. Available online: http://www. forbes.com.mx/10-consecuencias-economicas-de-la-reforma-energetica/ (accessed on 15 May 2015).

27. Miller, J.L.C. Reforma energética, era realmente necesaria? Econ. Inf. 2014, 2014, 3-45.

28. Gómez, M.A.; Alejo, F.J.; Navarrete, J.E.; Torres, R.C. Consideraciones sobre la Reforma de la Industria Petrolera en México. Econ. UNAM 2014, 11, 110-137. [CrossRef]

29. Reyes Hernández, M.; Moreno, H.M.; López, M.A.L.; Jiménez, J.A. The Denationalization of Pemex: Implications and Scope for Mexico. Lat. Am. Policy 2014, 5, 132-156. [CrossRef]

30. Vargas, R. Reforma energética: De servicio público a modelo de negocios. Política y Cultura 2015, 43, $125-145$.

31. Vargas, R. La Reforma Energética: A 20 años del TLCAN. Prob. Desarrollo 2015, 46, 103-127. [CrossRef]

32. Johansson Mondragón, S. Los Partidos Políticos Ante la Reforma Petrolera en México; Universidad Nacional Autónoma de México: Mexico City, Mexico, 2011.

33. Román-Morales, I. La Reforma Energética: Algo Más que una Reforma; ITESO: Jalisco, Mexico, 2014.

34. Márquez, D.I. Mexico's 2013 Energy Reform: Towards Energy Transition? Available online: http:/ /www.actualidadjuridicaambiental.com/wp-content/uploads/2014/11/2014_12_01_Iglesias-

D_Felipe-B_Reforma_energetica_Mexico.pdf (accessed on 18 March 2017).

35. Jamasb, T.; Nepal, R.; Timilsina, G.R. Energy Sector Reform, Economic Efficiency and Poverty Reduction; Durham University Business School: Durham, NC, USA, 2014.

36. Cypher, J.M. Developing Disarticulation within the Mexican Economy. Lat. Am. Perspect. 2001, $28,11-37$. [CrossRef]

37. Delgado, R.; Cypher, J.M. The Strategic Role of Mexican Labor under NAFTA: Critical Perspectives on Current Economic Integration. Ann. Amer. Acad. Polit. Soc. Sci. 2007, 610, 120-142.

38. Kopinak, K. Maquiladora industrialization of the Baja California peninsula: The coexistence of thick and thin globalization with economic regionalism. Int. J. Urban Reg. Res. 2003, 27, 319-336. [CrossRef]

39. Gonzalez-Canales, E. Mexican energy law: Industry renaissance or chronicle of a death foretold: Part 1: Upstream ventures in Mexico. J. World Energy Law Bus. 2015. [CrossRef]

40. Torres Flores, R.C. La reforma energética ¿coadyuva al desarrollo? Economía UNAM 2014, 11, $120-124$. [CrossRef]

41. Aguilera Gómez, M. CFE: Reforma institucional y de operación. In Seminario: El curso de la Reforma Energética; Programa Universitario de Estudios del Desarrollo: Mexico City, Mexico, 2015.

42. Tomecek, K. Mexican Energ y Revolution: But is it a Solution? Sustain. Dev. Law Policy 2015, 15, 15-16.

43. Del Río Portilla, A. Transición energética e impactos ambientales. In Seminario: El Curso de la Reforma Energética; Programa Universitario de Estudios del Desarrollo: Mexico City, Mexico, 2015.

44. Aguilar Sánchez, M. Impactos sociales y políticos. In Seminario: El Curso de la Reforma Energética; Programa Universitario de Estudios del Desarrollo: Mexico City, Mexico, 2015.

45. Guevara, Z.; Rodrigues, J.F.D. Structural transitions and energy use: A decomposition analysis of Portugal 1995-2010. Econ. Systems Res. 2016, 28, 202-223. [CrossRef]

46. Guevara, Z.; Domingos, T. The multi-factor energy input-output model. Energy Econ. 2017, 61, $261-269$. [CrossRef]

47. Hoekstra, R.; van den Bergh, J.C.J.M. Structural decomposition analysis of physical flows in the economy. Environ. Resour. Econ. 2002, 23, 357-378. [CrossRef]

48. Sheinbaum, C.; Ozawa, L. Energy use and $\mathrm{CO}_{2}$ emissions for Mexico's cement industry. Energy 1998, 23, 725-732. [CrossRef] 
49. Sheinbaum, C.; Ozawa, L.; Castillo, D. Using logarithmic mean Divisia index to analyze changes in energy use and carbon dioxide emissions in Mexico's iron and steel industry. Energy Econ. 2010, 32, 1337-1344. [CrossRef]

50. Sheinbaum, C.; Rodríguez, L. Recent trends in Mexican industrial energy use and their impact on carbon dioxide emissions. Energy Policy 1997, 25, 825-831. [CrossRef]

51. Berndt, E.R.; Botero, G. Energy demand in the transportation sector of Mexico. J. Devel. Econ. 1985, 17, 219-238. [CrossRef]

52. Ozawa, L.; Sheinbaum, C.; Martin, N.; Worrell, E.; Price, L. Energy use and CO2 emissions in Mexico's iron and steel industry. Energy 2002, 27, 225-239. [CrossRef]

53. Puyana-Mutis, A.; Santillán-Vera, M.; Pérez-Guzmán, K. The relation between oil production and the CO2 emissions of the manufacturing sector: A decomposition analysis of Mexico's industry from 1970-2010. Eur. Sci. J. 2014. Available online: http:/ / eujournal.org/index.php/esj/article/view/4054/3893 (accessed on 18 March 2017).

54. Aguayo, F.; Gallagher, K.P. Economic reform, energy, and development: The case of Mexican manufacturing. Energy Policy 2005, 33, 829-837. [CrossRef]

55. Sheinbaum, C.; Ruíz, B.J.; Ozawa, L. Energy consumption and related $\mathrm{CO}_{2}$ emissions in five Latin American countries: Changes from 1990 to 2006 and perspectives. Energy 2011, 36, 3629-3638. [CrossRef]

56. Ortiz, B.L. Análisis de requerimientos de energía con la metodología Insumo-Producto para el caso mexicano 1971-2007. Econ. Inf. 2011, 371, 43-51.

57. Alcántara, V.; Roca, J. Energy and CO2 emissions in Spain: Methodology of analysis and some results for 1980-1990. Energy Econ. 1995, 17, 221-230. [CrossRef]

58. Livas-García, A. Análisis de insumo-producto de energía y observaciones sobre el desarrollo sustentable, caso mexicano 1970-2010. Ingeniería, Investigación y Tecnología 2015, 16, 239-251.

59. Miller, R.E.; Blair, P.D. Input-Output Analysis: Foundations and Extensions, 2nd ed.; Cambridge University Press: Cambridge, MA, USA, 2009.

60. Casler, S.; Wilbur, S. Energy input-output analysis: A simple guide. Resour. Energy 1984, 6, $187-201$. [CrossRef]

61. Bullard, C.W.; Herendeen, R.A. The energy cost of goods and services. Energy Policy 1975, 3, $268-278$. [CrossRef]

62. Hoekstra, R.; van den Bergh, J.C.J.M. Comparing structural decomposition analysis and index decomposition analysis. Energy Econ. 2003, 25, 39-64. [CrossRef]

63. Rose, A.; Casler, S. Input-output structural decomposition analysis: A critical appraisal. Econ. Syst. Res. 1996, 8, 33-62. [CrossRef]

64. Ang, B.W.; Zhang, F.Q. A survey of index decomposition analysis in energy and environmental studies. Energy 2000, 25, 1149-1176. [CrossRef]

65. Su, B.; Ang, B.W. Structural decomposition analysis applied to energy and emissions: Some methodological developments. Energy Econ. 2012, 34, 177-188. [CrossRef]

66. Xu, X.Y.; Ang, B.W. Index decomposition analysis applied to $\mathrm{CO}_{2}$ emission studies. Ecolog. Econ. 2013, 93, 313-329. [CrossRef]

67. Liu, N.; Ang, B.W. Factors shaping aggregate energy intensity trend for industry: Energy intensity versus product mix. Energy Econ. 2007, 29, 609-635. [CrossRef]

68. Dietzenbacher, E.; Los, B. Structural decomposition techniques: Sense and sensitivity. Econ. Systems Res. 1998, 10, 307-324. [CrossRef]

69. Seibel, S. Decomposition Analysis of Carbon Dioxide Emission Changes in Germany: Conceptual Framework and Empirical Results; Federal Statistical Office of Germany: Luxembourg, 2003.

70. De Haan, M. A structural decomposition analysis of pollution in the Netherlands. Econ. Systems Res. 2001, 13, 181-196. [CrossRef]

71. Guevara, Z. Three-level energy decoupling: Energy decoupling at the primary, final and useful levels of energy use. Ph.D. Dissertation, University of Lisbon, Lisbon, Portugal, 2014.

72. Su, B.; Ang, B.W. Attribution of changes in the generalized Fisher index with application to embodied emission studies. Energy 2014, 69, 778-786. [CrossRef]

73. Su, B.; Ang, B.W. Multiplicative decomposition of aggregate carbon intensity change using input-output analysis. Appl. Energy 2015, 154, 13-20. [CrossRef] 
74. Su, B.; Ang, B.W. Multi-region comparisons of emission performance: The structural decomposition analysis approach. Ecol. Indic. 2016, 67, 78-87. [CrossRef]

75. EUROSTAT. Manual of Supply, Use and Input-Output Tables; European Comission: Luxembourg, 2008.

76. INE. E.6.1.2 Consumo de Energia Associado às Emissões; Instituto Nacional de Estadística: Lisbon, Portugal, 2013.

77. INEGI. Tablas Insumo-Producto de la Economía Nacional; Instituto Nacional de Estadística y Geografía: Mexico City, Mexico, 2014.

78. Dietzenbacher, E.; Temurshoev, U. Input-output impact analysis in current or constant prices: Does it matter? J. Econ. Struct. 2012, 1, 1-18. [CrossRef] [PubMed]

79. Dietzenbacher, E.; Hoen, A.R. Deflation of input-output tables from the user's point of view: A heuristic approach. Rev. Income Wealth 1998, 44, 111-122. [CrossRef]

80. Jackson, R.; Murray, A. Alternative input-output matrix updating formulations. Econ. Systems Res. 2004, 16, 135-148. [CrossRef]

81. Su, B.; Ang, B.W. Structural decomposition analysis applied to energy and emissions: Aggregation issues. Econ. Systems Res. 2012, 24, 299-317. [CrossRef]

82. Bhattacharyya, S.C. Energy Economics: Concepts, Issues, Markets and Governance; Springer: Dundee, Scotland, 2011.

83. IEA. What Are the Methods of Calculation of Primary Energy Equivalent? Available online: https://www. iea.org/statistics/resources/questionnaires/faq/\#one (accessed on 7 May 2014).

84. UN. Concepts and Methods in Energy Statistics with Special Reference to Energy Accounts and Balances: A Technical Report; United Nations: New York, NY, USA, 1982.

85. Lightfoot, H.D. Understand the three different scales for measuring primary energy and avoid errors. Energy 2007, 32, 1478-1483. [CrossRef]

86. Cegonho, N.; Delgado Domingos, J.; Domingos, T. Um novo método de cálculo de energia primária e a sua aplicação a Portugal. In IV Conferência Nacional em Mecânica dos Fluidos, Termodinâmica e Energia; University of Porto: Lisbon, Portugal, 2012.

(C) 2017 by the authors. Licensee MDPI, Basel, Switzerland. This article is an open access article distributed under the terms and conditions of the Creative Commons Attribution (CC BY) license (http://creativecommons.org/licenses/by/4.0/). 